\title{
Mechanisms of salt tolerance in seedlings of six woody native species of the Brazilian semi-arid ${ }^{1}$
}

\author{
Mecanismos de tolerância à salinidade em mudas de seis espécies arbóreas \\ nativas do semiárido brasileiro
}

\author{
Michele Campos Bessa ${ }^{2}$, Claudivan Feitosa Lacerda², Aiala Vieira Amorim*, Antonio Marcos Esmeraldo \\ Bezerra $^{4}$ and Alan Diniz Lima ${ }^{2}$
}

\begin{abstract}
The aim of this study was to evaluate the salt tolerance and physiological responses of six woody native species of the Caatinga ecosystem, on a soil salinity gradient in a greenhouse. The experimental design was of randomized blocks in a split-plot scheme; six plant species native of the Caatinga in the plots, and five levels of soil salinity in the sub-plots (1.2, 2.7, 4.7, 6.7 and $8.4 \mathrm{dS} \mathrm{m}^{-1}$ ), with five replications. The results demonstrate that species of the Caatinga ecosystem display a high capacity for adaptation in soils of low and moderate salinity. However, considering the reduction in total dry matter production at the highest salinity level, it was seen that only the species $M$. urundeuva was tolerant to salinity, and H. impetiginosus and E. velutina behaved as moderately tolerant. In the present study, it was also not possible to establish a clear relationship between the leaf gas exchange or the accumulation of organic solutes in the leaves with the degrees of salt tolerance. On the other hand, a strong relationship was seen between the $\mathrm{Na}^{+} / \mathrm{K}^{+}$ratio and the degree of tolerance of the species under study, with the more tolerant species displaying less variation and lower values with the increases in soil salinity. These species, however, showed a low capacity for retaining $\mathrm{Na}^{+}$in the stems, which may be a limiting factor on their use in revegetation projects of those areas degraded by secondary salinization.
\end{abstract}

Key words: Salt stress. Caatinga ecosystem. Woody plants. Leaf gas exchange.

RESUMO - No presente trabalho buscou-se avaliar o grau de tolerância à salinidade e os mecanismos fisiológicos de mudas de seis espécies lenhosas nativas da caatinga, sob um gradiente de salinidade do solo, em casa de vegetação. Utilizou-se um delineamento em bloco ao acaso, em parcelas subdivididas, com cinco repetições, sendo as parcelas formadas pelas seis espécies e as subparcelas pelos níveis de salinidade do solo $\left(1,2 ; 2,7 ; 4,7 ; 6,7 ;\right.$ e $\left.8,4 \mathrm{dS} \mathrm{m}^{-1}\right)$. Os resultados demonstram que as espécies da Caatinga exibem uma elevada capacidade de adaptação em solos de salinidade baixa e moderada. Entretanto, considerando-se os graus de redução na produção de matéria seca total, no maior nível de salinidade, observou-se que apenas a espécie $M$. urundeuva mostrou-se tolerante à salinidade; H. impetiginosus e E. velutina se comportaram como moderadamente tolerantes. No presente estudo, também não foi possível estabelecer uma relação clara entre as trocas gasosas e o acúmulo de solutos orgânicos nas folhas com os graus de tolerância ao sal. Por outro lado, uma forte relação foi observada entre a razão $\mathrm{Na}^{+} /$ $\mathrm{K}^{+}$e o grau de tolerância das espécies em estudo, com as espécies mais tolerantes apresentando menos variação e valores mais baixos com o aumento da salinidade do solo. Estas espécies, contudo, mostraram uma baixa capacidade de retenção de $\mathrm{Na}^{+}$ nos caules, que pode ser um fator limitante na sua utilização em projetos de revegetação em áreas degradadas por salinização secundária.

Palavras-chave: Estresse salino. Caatinga. Plantas lenhosas. Trocas gasosas.

\footnotetext{
DOI: $10.5935 / 1806-6690.20170018$

*Autor para correspondencia

${ }^{1}$ Recebido para publicação em 27/01/2016; aprovado em 09/05/2016

Pesquisa financiada pelo CNPq e parte da Dissertação da primeira autora

${ }^{2}$ Departamento de Engenharia Agrícola, Centro de Ciência Agrárias, Universidade Federal do Ceará, Fortaleza-CE, Brasil, michele_bessa@ hotmail.com, cfeitosa@ufc.br, alandinizlima@yahoo.com.br

${ }^{3}$ Instituto de Desenvolvimento Rural, Universidade da Integração Internacional da Lusofonia Afro-Brasileira, Av. da Abolição 3,Centro, Redenção-CE, Brasil, 62.790-000, aialaamorim@unilab.edu.br

${ }^{4}$ Departamento de Fitotecnia, Centro de Ciência Agrárias, Universidade Federal do Ceará, Fortaleza-CE, Brasil, esmeraldobezerra@yahoo.com.br
} 


\section{INTRODUCTION}

Caatinga, the predominant vegetation of the Brazilian semi-arid region, includes species with a high potential for use as timber, which are readily adaptable to different soil conditions as well as to the natural difficulties of the semi-arid climate. These species can be an important alternative in the utilization of saline areas where exploiting many agricultural species is not viable economically, and can contribute to supply of plant products in the northeast, and in reducing pressure on the native vegetation. However, information on the adaptability to saline conditions of species of the Caatinga is still scarce.

Salinity is one of the abiotic stresses that most limits plant production. It is estimated that $19.5 \%$ of the irrigated areas in the world, corresponding to 45 million hectares, are facing problems because of salinity. In Brazil, although the information on the salt affected areas is not well defined, it is estimated that 20 to $25 \%$ of irrigated areas in the Northeast region face problems of soil salinization (FAO, 2006). Part of these degraded saline areas, which are unsuitable for conventional crops, can be used to grow alternative plants to serve as a source of food, fuel, fodder, fiber, resin, essential oils and pharmaceutical products, and also for landscape reintegration (JOSEPH et al., 2013; RAISON, 2006).

In many parts of the world, an extensive area of secondary salinity is caused by bad management practices, poor water quality and the replacement of deeprooted, perennial native vegetation by shallow-rooted annual species (DALE; DIETERS, 2007). These facts contribute to a rise in the water table, bringing the salt stored deep in the profileto the soil surface. One solution to landscape salinity lies in the reintegration of trees and other perennial species back into agricultural systems with the aim of returning hydrological functions to a condition which mimics that of the original landscape (BARRETTLENNARD, 2002).

Several authors have reported the effects of salinity on development in perennial species (BUSH et al., 2013; FEIKEMA; BAKER, 2011), with the majority of studies concentrating on the early stages of development (MORAIS et al., 2012; PATEL; PANDEY, 2007). These studies are important, since the success of reforestation is dependent, among other factors, on the ability of seedlings to withstand, and become established under adverse environmental conditions (NOVOA et al., 2013).

An excess of salts in the soil can disturb the physiological and biochemical functions of cells, leading to the death of the plant. Plants exposed to high salt concentrations generally face two problems: the first is the absorption of water from soil with a low osmotic potential; the second results from the accumulation of toxic ions in the cytoplasm, which inhibit many metabolic reactions. This osmotic and ionic imbalance leads to a reduction in carbon assimilation, in the absorption of nutrients and in the growth of the plant (MUNNS; TESTER, 2008). The inhibition of carbon assimilation has been attributed to reductions in stomatal conductance, as well as to the accumulation of the $\mathrm{Na}^{+}$and/or $\mathrm{Cl}^{-}$ions, which adversely affect the biochemical and photochemical processes involved in photosynthesis (NEDJIMI, 2009).

The aim of this study therefore was to evaluate the tolerance and physiological responses of six woody native species of the Caatinga ecosystem (Myracrodruon urundeuva, Handroanthus impetiginosus, Bauhinia unguculata, Erythrina velutina, Mimosa caesalpiniifolia and Luetzelburgia auriculata), on a soil salinity gradient in a greenhouse, with a view to benefitting the establishment of species which are promising under field conditions. These species chosen have high wood production potential in the Northeast Brazil, being considered of high economic importance (FIGUEIRÔA et al., 2005).

\section{MATERIAL AND METHODS}

The experiment was carried out in a greenhouse located on the Pici Campus of the Federal University of Ceará (UFC) in Fortaleza, in the state of Ceará, Brazil ( $3^{\circ} 44^{\prime} \mathrm{S}, 38^{\circ} 33^{\prime} \mathrm{W}$ and $20 \mathrm{~m}$ altitude). The experimental design was of randomized blocks in a split-plot scheme; six woody native species of the Caatinga in the plots, and five levels of soil salinity in the sub-plots, with five replications, giving 300 experimental units. An experimental unit consisted of two pots containing one plant each.

The six species of plants used from the Caatinga were:

1. Myracrodruon urundeuva Fr Allemao - represented by MU;

2. Handroanthus impetiginosus, represented by HI;

3. Bauhinia unguculata L. - represented by BU;

4. Erythrina velutina Willd. - represented by EV;

5. Mimosa caesalpiniifolia Benth. - represented by MC;

6. Luetzelburgia auriculata (Allemao) Ducke represented by LA.

The seedlings were grown in a greenhouse under $50 \%$ shade. They were planted in styrofoam trays each of 128 cells, and a substrate of sand + vermicompost in a ratio of $2: 1$, 
where they remained for 20 days, irrigated daily by means of a micro-sprinkler system with well water at an electrical conductivity of $0.7 \mathrm{dS} \mathrm{m} \mathrm{m}^{-1}$.

To make up the saline treatments, a soil classified as Fluvent, was collected at five different points of the Morada Nova Irrigated District, in Ceará, Brazil. The sites were selected based on in situ analysis of the electrical conductivity of the soil in the 0 to $20 \mathrm{~cm}$ layer, using a Wet Jet sensor (Delta-T Devices, Cambridge, England). After collection, all clumps were removed from the soil, which was then passed through a $5 \mathrm{~mm}$ mesh sieve. The electrical conductivity of the saturated soil (EC) was measured, resulting in the five saline treatments used $\left(1.2,2.7,4.7,6.7\right.$ and $\left.8.4 \mathrm{dS} \mathrm{m}^{-1}\right)$. Measurement of the EC was carried out directly on the saturated paste, and presented a high correlation $(r=0.99)$ with the electrical conductivity of the saturation extract, expressed by the following equation: $\mathrm{EC}_{\mathrm{es}}=0.84 \mathrm{EC}$. The main chemical characteristics of the soil are shown in Table 1.

At 20 days after sowing, the seedlings were selected according to their uniformity, and then transplanted into 5-liter capacity, black plastic polyethylene pots, containing a bottom layer of $3 \mathrm{~cm}$ of gravel immediately followed by the soils at different levels of salinity. To reduce the impact of direct contact of the root system of the plants with the saline soil, especially in those treatments at higher salinity levels, a suitable amount of washed river sand was added to the holes in each pot. After transplanting, the plants remained in the pots for a period of 90 days, being irrigated daily with well water at an electrical conductivity of $0.7 \mathrm{dS} \mathrm{m^{-1 }}$ by means of a microsprinkler system.

At 90 days after transplanting, measurements were made of stomatal conductance $\left(\mathrm{g}_{\mathrm{s}}\right)$, rate of transpiration $(E)$ and net assimilation rate $(A)$, on fully expanded leaves using an IRGA (Model ADC-System, ADC, UK). The two measurements were taken between 8:00 am and 11:00 am under natural conditions (temperature and $\mathrm{CO}_{2}$ concentration) and coupled to an artificial lighting at an intensity of about $1,500 \mu \mathrm{mol} \mathrm{m} \mathrm{m}^{-1} \mathrm{~s}^{-1}$. From the measurements obtained, the intrinsic water use efficiency $\left(A / g_{s}\right)$ and momentary water use efficiency $(A / E)$ were estimated (SILVA et al., 2013).

Measurements of the photochemical efficiency of photosystem II using a fluorometer (Plant Efficiency Analyser, Hansatech Instruments Ltd, Norfolk, England), were also performed. These measurements were taken from the same leaves used when measuring gas exchange.

At 90 days after transplanting, the shoots were collected and, after drying in oven at $65{ }^{\circ} \mathrm{C}$, the total production of dry biomass was obtained. The percentage losses were then calculated for the lowest salinity level (reduction in \%), which were used as indices to compare the tolerance of the six woody native species, being classified as tolerant ( 0 to $20 \%$ reduction), moderately tolerant (21 to $40 \%$ reduction), moderately susceptible (41 to $60 \%$ reduction) or susceptible (above $60 \%$ reduction), according to Fageria (1985).

Samples of the leaf blades were lyophilized and ground, and then used in determining the levels of organic and inorganic solutes. Crude extracts were prepared according to the method of Cataldo et al. (1975). In the extracts, concentrations were determined for soluble carbohydrates (DUBOIS et al., 1956), soluble aminoN (YEMM; COCKING; RICKETTS, 1955), proline (BATES; WALDREN; TEARE, 1973), and $\mathrm{Na}^{+}, \mathrm{K}^{+}$ (GAINES; PARKER; GASCHO, 1984; MALAVOLTA; VITTI; OLIVEIRA, 1989).

The data for each characteristic under evaluation were submitted to variance analysis and, when significant by F-test, submitted to the Tukey means test at $\mathrm{P}<0.05$ (comparison between species), and to regression analysis (isolated effects of salinity and of the interaction between factors). The Assistat 7.6 beta software was used in the analysis.

Table 1 - Chemical characteristics of the soil used in the experiment

\begin{tabular}{|c|c|c|c|c|c|c|}
\hline \multirow{2}{*}{$\mathrm{EC}\left(\mathrm{dS} \mathrm{m} \mathrm{m}^{-1}\right)$} & $\mathrm{K}$ & $\mathrm{Ca}$ & $\mathrm{Mg}$ & $\mathrm{Na}$ & $\mathrm{CCE}^{1}$ & \multirow{2}{*}{ ESP \% } \\
\hline & \multicolumn{5}{|c|}{$\mathrm{mmol}_{\mathrm{c}} \mathrm{dm}^{-3}$} & \\
\hline 1.2 & 2.76 & 41.5 & 46.5 & 8.91 & 109.6 & 8 \\
\hline 2.7 & 2.17 & 74.0 & 38.5 & 25.00 & 142.2 & 18 \\
\hline 4.7 & 2.56 & 96.5 & 74.0 & 51.74 & 238.8 & 22 \\
\hline 6.7 & 4.14 & 131.5 & 108.5 & 121.74 & 370.0 & 33 \\
\hline 8.4 & 3.76 & 94.0 & 75.0 & 127.83 & 302.3 & 42 \\
\hline
\end{tabular}

${ }^{1} \mathrm{CCE}=$ capacity of cations exchange; $\mathrm{ESP}=$ exchangeable sodium percentage 


\section{RESULTS AND DISCUSSION}

It can be seen in Table 2, that for an EC of $2.7 \mathrm{dS} \mathrm{m} \mathrm{m}^{-1}$, the six species under study were classified as tolerant to salinity, with the lowest percentage decreases being observed for the species $M$. urundeuva, $H$. impetiginosus and E. velutina. This trend was also seen for the other saline levels (4.7, 6,7 and $8.4 \mathrm{dS} \mathrm{m}^{-1}$ ), with the species L. auriculata, B. unguculata and $M$. caesalpiniifolia achieving reductions close to or greater than $50 \%$ with the treatment at the highest salinity; the first two being classified as moderately sensitive and the third as sensitive.

Leaf gas exchange differed between the species under study, and were affected by the salinity $(\mathrm{P}<0.01$ or $\mathrm{P}<0.05)$. However, the interaction between factors was not significant $(\mathrm{P}<0.05)$, while none of the factors influenced the $\mathrm{Fv} / \mathrm{Fm}$ ratio $(\mathrm{P}>0.05)$.

In Figure 1A can be seen the differences in stomatal conductance between the six woody native species. It shows that B. unguculata and $M$. caesalpiniifolia did not differ by Tukey test ( $p>0.05)$, having the largest values for $\mathrm{g}_{\mathrm{s}}, 0.436$ and $0.371 \mathrm{~mol} \mathrm{~m}^{-2} \mathrm{~s}^{-1}$ respectively. The lowest values for $\mathrm{g}_{\mathrm{s}}$ were observed in the M. urundeuva and $H$. impetiginosus, which also had the lowest net assimilation rate (Figure 1C) and transpiration (Figure 1E). Furthermore, it can be seen that the salinity, regardless of the species studied, resulted in linear decreases in stomatal conductance (Figure 1B), net assimilation rate (Figure 1D), and transpiration (Figure 1F).

The species $M$. urundeuva, $H$. impetiginosus and E. velutina displayed the highest values for intrinsic water use efficiency $\left(\mathrm{A} / \mathrm{g}_{\mathrm{s}}\right)$, while $L$. auriculata and $M$. caesalpiniifolia had significantly lower values (Figure 2A). On the other hand, it can be seen that the salinity resulted in a linear increase in the $A / g_{s}$ ratio regardless of the species studied (Figure 2B).
The lack of interaction between species and levels of soil salinity in relation to leaf gas exchange (Figure 1) indicates that the effects of salinity on these physiological variables were different from those observed in the production of dry biomass, with only the latter allowing the identification of different degrees of salt tolerance in the six species (Table 2). However, greater stomatal control (Figure 1A) and greater intrinsic water use efficiency (Figure 2A) can be seen in the species that display greater degrees of salt tolerance (Table 2), i.e. $M$. urundeuva, T. impetiginosa and E. velutina. The first two species displayed lower rates of net assimilation rate, but due to strong stomatal control, succeeded in maintaining high water use efficiency, which may have contributed to the greater degree of salt tolerance observed.

Stomatal closure in response to increased salinity plays an adaptive role because it controls the water flow in the system and the transport of toxic ions to the photosynthetic tissue, at the same time avoiding water loss through transpiration. In this study, it was found that salinity caused linear reductions in $g_{s}$ and $A$, with a larger decrease in stomatal conductance and increase in the $A / g s$ ratio, but without affecting the maximum efficiency of photosystem II, measured by the Fv/Fm ratio. A greater difference between the species was also found in terms of stomatal conductance than in terms of the rate of net assimilation rate. These results suggest that stomatal closure was primarily responsible for the reductions in carbon assimilation (KOYRO et al., 2013).

Stiller (2009) found that moderate salt stress did not affect the biochemical stage of photosynthesis in the leaves of Taxodium distichum, but due to stomatal closure, a $50 \%$ reduction was seen in the rate of leaf gas exchange in plants subjected to salinity. This response represents a mechanism of acclimation to salt stress, reducing the amount of water lost by transpiration, but also restricting $\mathrm{CO}_{2}$ assimilation (MELONI; GULOTTA; MARTINEZ, 2008).

Table 2 - Percentage of reduction in total dry mass of six native woody species from Caatinga ecosystem under a gradient of soil salinity

\begin{tabular}{|c|c|c|c|c|}
\hline \multirow{2}{*}{ Species } & \multicolumn{4}{|c|}{ Percentage of reduction $(\%)$} \\
\hline & $2.7 \mathrm{dS} \mathrm{m}^{-1}$ & $4.7 \mathrm{dS} \mathrm{m}^{-1}$ & $6.7 \mathrm{dS} \mathrm{m}^{-1}$ & $8.4 \mathrm{dS} \mathrm{m}^{-1}$ \\
\hline MU & $4.16^{\mathrm{T}}$ & $9.72^{\mathrm{T}}$ & $15.27^{\mathrm{T}}$ & $19.99^{\mathrm{T}}$ \\
\hline HI & $5.49^{\mathrm{T}}$ & $12.81^{\mathrm{T}}$ & $20.13^{\mathrm{MT}}$ & $26.35^{\mathrm{MT}}$ \\
\hline BU & $10.74^{\mathrm{T}}$ & $24.36^{\mathrm{MT}}$ & $37.98^{\mathrm{MT}}$ & $49.55^{\mathrm{MS}}$ \\
\hline $\mathrm{EV}$ & $5.26^{\mathrm{T}}$ & $12.27^{\mathrm{T}}$ & $19.29^{\mathrm{T}}$ & $25.25^{\mathrm{MT}}$ \\
\hline LA & $11.67^{\mathrm{T}}$ & $27.24^{\mathrm{MT}}$ & $42.80^{\mathrm{MS}}$ & $56.03^{\mathrm{MS}}$ \\
\hline $\mathrm{MC}$ & $13.20^{\mathrm{T}}$ & $30.80^{\mathrm{MT}}$ & $48.40^{\mathrm{MS}}$ & $63.36^{\mathrm{s}}$ \\
\hline
\end{tabular}

${ }^{\text {T, }}{ }^{\text {MT }}$, MS and ${ }^{\mathrm{S}}$ - Tolerant, moderately tolerant, moderately sensitive and sensitive, respectively 
Figure 1 - Stomatal conductance $\left(\mathrm{g}_{\mathrm{s}}\right)$, net assimilation rate $(A)$, and transpiration $(E)$ of six native woody species from Caatinga ecosystem (A, C and E), and as a function of soil salinity (B, D e F)
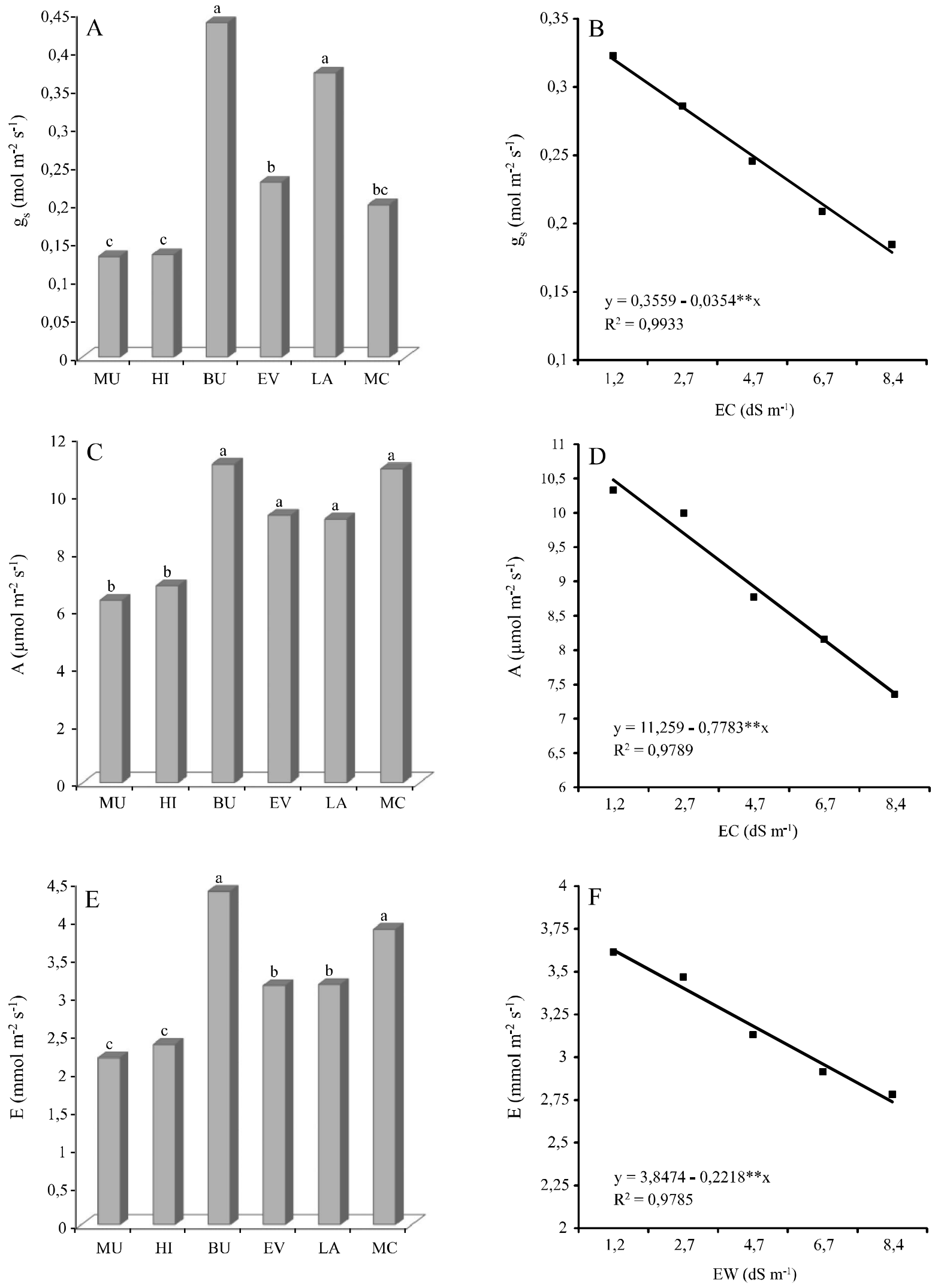
Figure 2 - Intrinsic water use efficiency of six native woody species from Caatinga ecosystem (A), and as a function of soil salinity (B)
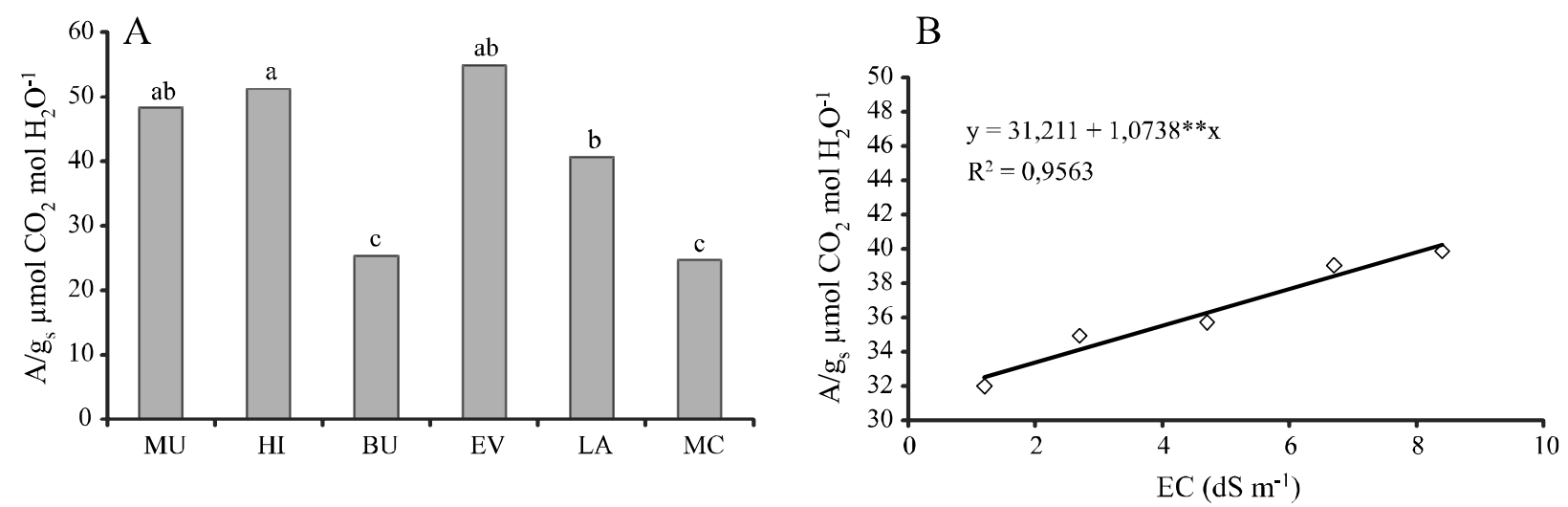

The levels of organic solutes differed between species $(\mathrm{P}<0.01)$, and it was found that the interaction between the factors species and salinity significantly influenced the levels of soluble amino-N $(\mathrm{P}<0.01)$, proline $(\mathrm{P}<001)$ and carbohydrates $(\mathrm{P}<0.05)$.

The concentrations of soluble amino-N in the leaves of B. unguculata, L. auriculata and M. caesalpiniifolia fit the quadratic polynomial regression models, with only $E$. velutina presenting a linear fit (Figure 3A). M. urundeuva and $T$. impetiginosa did not fit any regression equation and were the species with the lowest values at all salinity levels. The greatest accumulations of soluble amino-N were observed for E. velutina and L. auriculata. In general, the levels of soluble amino-N either increased or did not change in response to the increase in soil salinity, with the greatest increases being found for $M$. caesalpiniifolia (29\%) when comparing the extreme levels of soil salinity $\left(1.2\right.$ and $\left.8.4 \mathrm{dS} \mathrm{m}^{-1}\right)$.

The species $M$. urundeuva and M. caesalpiniifolia were noted for having the highest and lowest levels of carbohydrates, respectively (Figure 3B). The response of the plants fit the quadratic polynomial equations, except for M. urundeuva and M. caesalpiniifolia, which had cubic and linear adjustments, respectively. M. urundeuva displayed losses of $7.4 \%$ in carbohydrate levels for the increase in soil salinity, when comparing the extreme levels (EC 1.2 and $8.4 \mathrm{dS} \mathrm{m}^{-1}$ ), while E. velutina saw a gain of $19.8 \%$ under the same conditions.

As to proline levels in the leaves (Figure 3C), all of the regression curves fitted the quadratic or cubic polynomial models. Among the six species, M. urundeuva stands out due to a $71 \%$ decrease in proline levels when comparing the extreme levels of soil salinity (EC 1.2 and $8.4 \mathrm{dS} \mathrm{m}^{-1}$ ), while other species had increases, reaching $108 \%$ in L. auriculata, $238 \%$ in M. caesalpiniifolia and $254 \%$ in $H$. impetiginosus.

The accumulation of organic solutes may represent an adaptive advantage to salinity for the plants, in view of the role attributed to such solutes in osmotic adjustment and the protection of cell structures under conditions of salt stress (MELONI; GULOTTA; MARTINEZ, 2008; NEDJIMI, 2009; RADIĆ et al., 2013). However, in the present study it was not possible to establish a clear relationship between the accumulation of soluble amino-N, carbohydrates and proline (Figure 3), and salt tolerance for the six species being studied (Table 2). It is noteworthy that M. urundeuva, which displayed a higher degree of salt tolerance, showed both higher levels of soluble carbohydrates, irrespective of the level of salinity, and a reduction in proline levels, with the increase in electrical conductivity of the soil. Also noteworthy is the large accumulation of proline in M. caesalpiniifolia, which displayed a greater sensitivity to the imposed salt stress. This agrees with other authors who also found an inverse correlation between proline levels and tolerance to salt stress (LACERDA et al., 2003).

The greatest values for the $\mathrm{Na}^{+} / \mathrm{K}^{+}$ratio in the leaves were seen in the species $L$. auriculata, $B$. unguculata and M. caesalpiniifolia, showing that these genotypes have a lower capacity for controlling the absorption of these ions (Figure 4A), reaching values higher than 1,0 in L. auriculata. Furthermore, the stem $\mathrm{Na}^{+}$to leaf $\mathrm{Na}^{+}$ratio showed a linear increase in plants of $M$. caesalpiniifolia, while the other species fit either quadratic or cubic polynomial equations (Figure 4B), with values of generally less than 1.0 for this ratio.

The $\mathrm{Na}^{+} / \mathrm{K}^{+}$ratio has been used as a criterion in the selection of materials which are sensitive and tolerant to salt stress, since many authors report a correlation between salt tolerance, reductions in $\mathrm{Na}$ accumulation and the proper maintenance of potassium 
Figure 3 - Concentration of soluble N-amino (A), soluble carbohydrates (B), and proline (C) in leaves of six woody native species from Caatinga ecosystem as a function of soil salinity

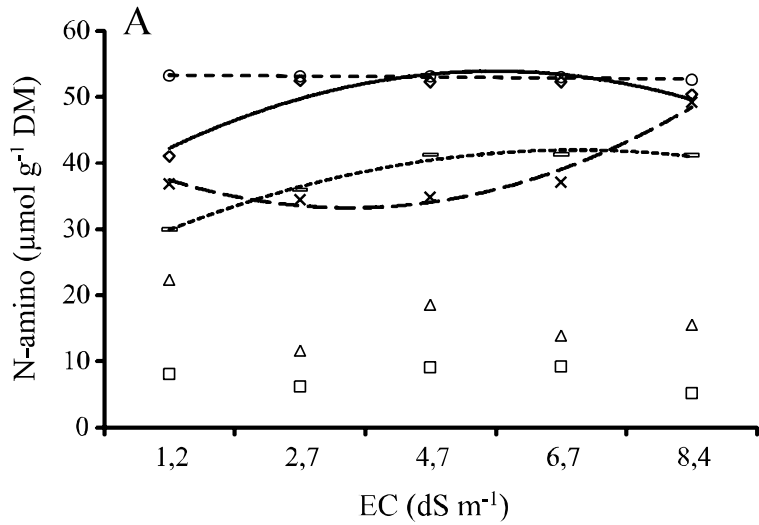

$\triangle \mathrm{MU}$

$\square \mathrm{HI}$

- $\mathrm{BU} \mathrm{y}=24,168+5,4557 * * \mathrm{x}-0,4138^{*} \mathrm{x}^{2} \quad \mathrm{R}^{2}=0,988$

$\diamond$ LA $\mathrm{y}=35,688+6,558^{* *} \mathrm{x}-0,5846^{*} \mathrm{x}^{2} \quad \mathrm{R}^{2}=0,815$

$\times \mathrm{MC} y=42,624-5,156 * * \mathrm{x}+0,6942 * \mathrm{x}^{2} \quad \mathrm{R}^{2}=0,952$

O EV $\mathrm{y}=53,372-0,0781 * \mathrm{x} \quad \mathrm{R}^{2}=0,748$

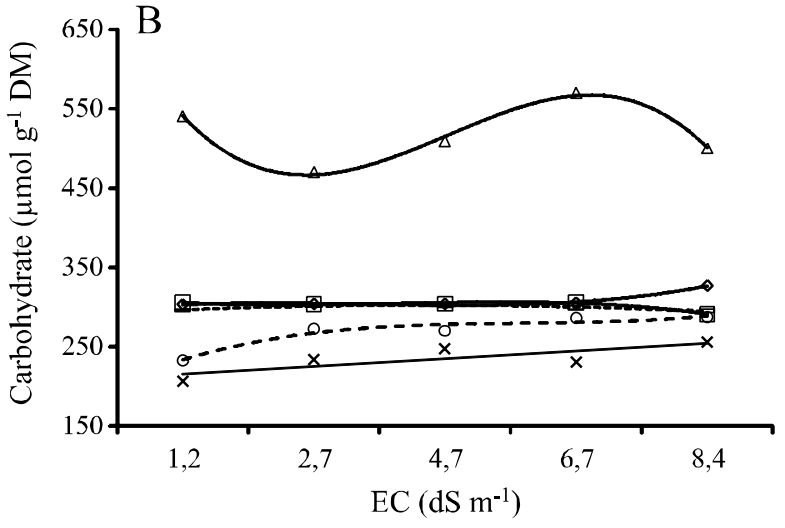

$\triangle$ MU $y=716,77-201,46 * * x+49,75^{*} x^{2}-3,431 x^{* 3} \quad R^{2}=0,9966$

口 HI $\mathrm{y}=299,49+4,1079 * * \mathrm{x}-0,577 * \mathrm{x}^{2} \quad \mathrm{R}^{2}=0,7188$

- BU $\quad \mathrm{y}=291,66+4,8794 * * x-0,5411 * \mathrm{x}^{2} \quad \mathrm{R}^{2}=0,8775$

○ LA $y=311,82-6,6913 * * x+0,975 * x^{2} \quad R^{2}=0,8839$

$\times \mathrm{MC} \quad \mathrm{y}=211,07+5,0559 * * \mathrm{x} \quad \mathrm{R}^{2}=0,8839$

○ EV $\mathrm{y}=217,39+19,104 * * \mathrm{x}-1,3058^{*} \mathrm{x}^{2} \quad \mathrm{R}^{2}=0,856$
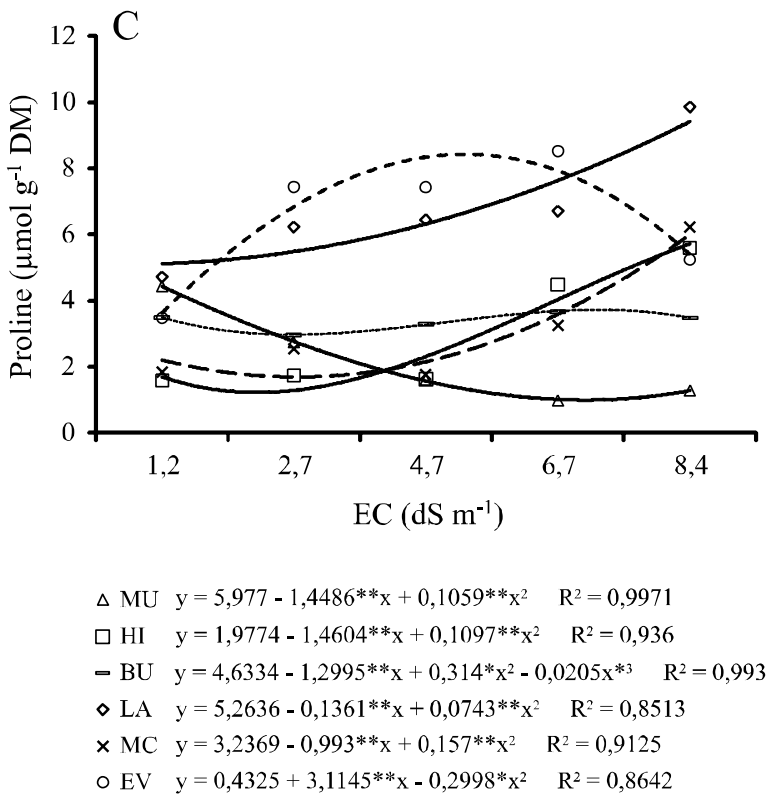

nutrition (MELCHIORRE et al., 2009; NEDJIMI, 2009). In the present study there was a strong relationship between the $\mathrm{Na}^{+} / \mathrm{K}^{+}$ratio in the leaves (Figure 4A) and the degree of salt tolerance obtained based on the production of dry biomass (Table 2); the most tolerant species (M. urundeuva, H. impetiginosus and $E$. velutina) displaying the smallest variations and lowest values with the increases in soil salinity.
Despite some increases seen in the stem $\mathrm{Na}^{+} / \mathrm{leaf}$ $\mathrm{Na}^{+}$ratio, these were smaller or slightly more than 1.0 , a value far lower than those observed in other studies. For example, Aquino et al. (2007), working with sorghum irrigated with saline water, found that the salinity caused a 12-fold increase in the ratio between $\mathrm{Na}^{+}$in the stems and sheaths relative to their levels in the leaf blades. The above authors concluded that this increase is a good 
Figure 4 - Leaf $\mathrm{Na}^{+} / \mathrm{K}^{+}$ratio (A) and ratio between $\mathrm{Na}^{+}$concentration in stems and leaves of six native woody species from Caatinga ecosystem as a function of soil salinity

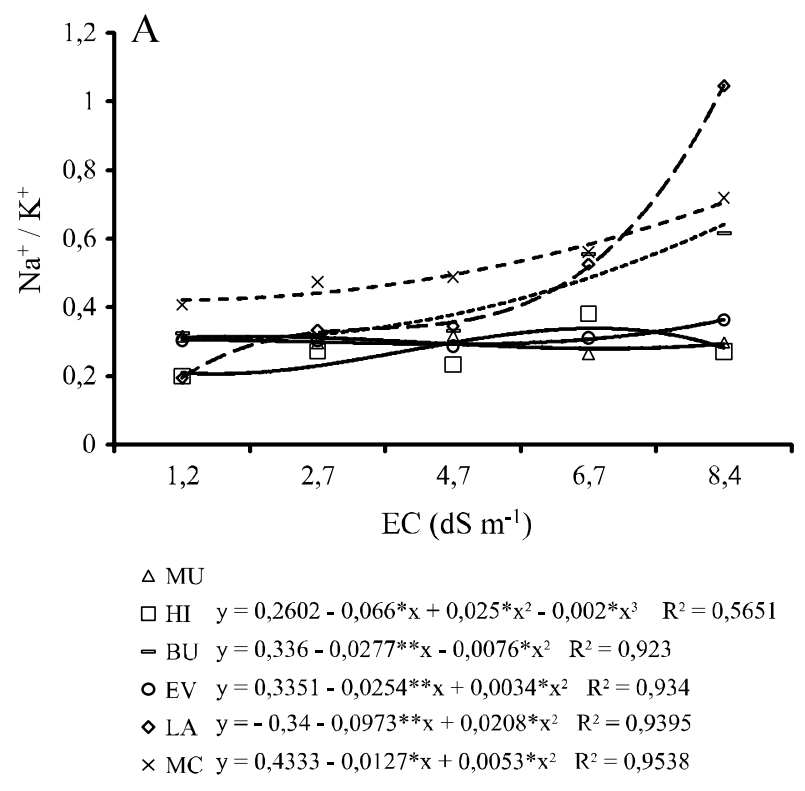

indicator of the capacity for retaining potentially toxic ions, primarily $\mathrm{Na}^{+}$, suggesting that this species exports little $\mathrm{Na}^{+}$from the stems to the leaves, thereby avoiding an excess of the ion in photosynthetic tissue. The results obtained in the present study (Figure 4) suggest that the woody species being tested have little capacity for retaining $\mathrm{Na}^{+}$in the stems and petioles, a fact that results in greater sensitivity to salinity and which may contribute to the replacement of native species by invasive species in areas affected by salts.

\section{CONCLUSIONS}

1. Considering the reduction in total dry matter production at the highest salinity level, it was seen that only the species $M$. urundeuva was tolerant (T) to salinity, $H$. impetiginosus and E. velutina behaved as moderately tolerant (MT), L. auriculata and B. unguculata moderately sensitive (MS), and M. caesalpiniifolia was classified as sensitive (S);

2. Salinity caused a decrease in foliar gas exchange, with no differences in terms of tolerance being seen based on these physiological variables. However, greater stomatal control and intrinsic water use efficiency are seen in species that display higher degrees of salt tolerance, i.e. M. urundeuva, $H$. impetiginosus and E. velutina;

3. A strong relationship was seen between the $\mathrm{Na}^{+} / \mathrm{K}^{+}$ ratio and the degree of tolerance of the species under

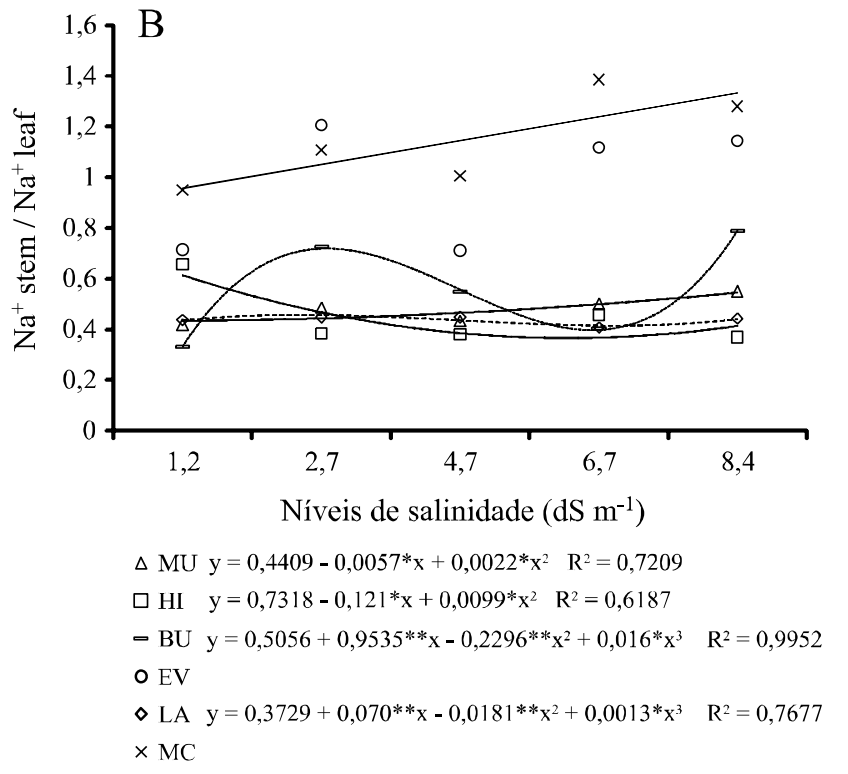

study, with the more tolerant species displaying less variation and lower values with the increases in soil salinity.

\section{ACKNOWLEDGEMENTS}

Acknowledgments are due to the Conselho Nacional de Desenvolvimento Científico e Tecnológico (CNPq), Instituto Nacional de Ciência e Tecnologia em Salinidade (INCTSal), and Fundação Cearense de Apoio ao Desenvolvimento Científico e Tecnológico, all these institutions from Brazil, for financial support.

\section{REFERENCES}

AQUINO, A. J. S. et al. Crescimento, partição de matéria seca e retenção de $\mathrm{Na}^{+}, \mathrm{K}^{+}$e $\mathrm{Cl}^{-}$em dois genótipos de sorgo irrigados com águas salinas. Revista Brasileira de Ciências do Solo, v. 31, n.5, p. 961-971, 2007.

BARRETT-LENNARD, E. G. Restoration of saline land through revegetation. Agricultural Water Management, v. 53, n. 1, p. 213-226, 2002.

BATES, L. S.; WALDREN, R. P.; TEARE, I. D. Rapid determination of free proline for water-stress studies. Plant and Soil, v. 39, n. 1, p. 205-207, 1973.

BUSH, D. et al. Assessing genetic variation within Eucalyptus camaldulensis for survival and growth on two spatially 
variable saline sites in southern Australia. Forest Ecology and Management, v. 306, n. 1, p. 68-78, 2013.

CATALDO, D. A. et al. Rapid colorimetric determination of nitrate in plant tissue by nitration of salicylic acid 1 . Communications in Soil Science \& Plant Analysis, v. 6, n. 1, p. 71-80, 1975.

DALE, G.; DIETERS, M. Economic returns from environmental problems: breeding salt-and drought-tolerant eucalypts for salinity abatement and commercial forestry. Ecological Engineering, v. 31, n. 3, p. 175-182, 2007.

DUBOIS, M. et al. Colorimetric method for determination of sugars and related substances. Analytical Chemistry, v. 28, n. 3, p. $350-356,1956$.

FAGERIA, N. K. Salt tolerance of rice cultivars. Plant and Soil, v. 88, n. 2, p. 237-243, 1985.

FEIKEMA, P. M.; BAKER, T. G. Effect of soil salinity on growth of irrigated plantation Eucalyptus in south-eastern Australia. Agricultural Water Management, v. 98, n. 7, p. 1180-1188, 2011.

FIGUEIRÔA, J. M. et al. Madeireiras. In: SAMPAIO, E. V. S. (Ed.). Espécie da flora nordestina de importância econômica potencial. Recife: Associação Plantas do Nordeste, 2005, p. 101-133.

FOOD AND AGRICULTURE ORGANIZATION. (2006) Disponível em:< http://www.fao.org/soils-portal/soilmanagement/management-of-some-problem-soils/salt-affectedsoils/en/ > . Acesso em: $10 \mathrm{dez} .2015$.

GAINES, T. P.; PARKER, M. B.; GASCHO, G. J. Automated determination of chlorides in soil and plant tissue by sodium nitrate extraction. Agronomy Journal, v. 76, n. 3, p. 371-374, 1984.

JOSEPH, S. et al. Application of molecular markers for identification of potential salt tolerant plant species for use in agroforestry and saline land eclamation. APCBEE Procedia, v. 5, n. 1, p. 514-519, 2013.

KOYRO, H-W et al. Photosynthetic and growth responses of a perennial halophytic grass Panicum turgidum to increasing $\mathrm{NaCl}$ concentrations. Environmental and Experimental Botany, v. 91, n. 1, p. 22-29, 2013.

LACERDA, C. F. et al. Solute accumulation and distribution during shoot and leaf development in two sorghum genotypes under salt stress. Environmental and Experimental Botany, v. 49, n. 2, p. 107-120, 2003.

MALAVOLTA, E.; VITTI, G. C.; OLIVEIRA, S. A. Avaliação do estado nutricional das plantas: princípios e aplicações. 2. ed.
Piracicaba: Associação Brasileira para Pesquisa da Potassa e do Fosfato, 1989. 201 p.

MELCHIORRE, M. et al. Physiological characterization of four model Lotus diploid genotypes: L. japonicus (MG20 and Gifu), L. filicaulis, and L. burttii under salt stress. Plant Science, v. 177, n. 6, p. 618-628, 2009.

MELONI, D. A.; GULOTTA, M. R.; MARTINEZ, C. A. Salinity tolerance in Schinopsis quebracho colorado: seed germination, growth, ion relations and metabolic responses. Journal of Arid Environments, v. 72, n. 10, p. 1785-1792, 2008.

MORAIS, M. C. et al. Salt tolerance traits increase the invasive success of Acacia longifolia in Portuguese coastal dunes. Plant Physiology and Biochemistry, v. 55, n. 1, p. 60-65, 2012.

MUNNS, R.; TESTER, M. Mechanisms of salinity tolerance. Annual Reviews Plant Biology, v. 59, n. 1, p. 651-681, 2008.

NEDJIMI, B. Salt tolerance strategies of Lygeum spartum L.: a new fodder crop for Algerian saline steppes. FloraMorphology, Distribution, Functional Ecology of Plants, v. 204, n. 10, p. 747-754, 2009.

NOVOA, A. et al. Constraints to native plant species establishment in coastal dune communities invaded by Carpobrotus edulis: implications for restoration. Biological Conservation, v. 164, n. 1, p. 1-9, 2013.

PATEL, A. D.; PANDEY, A. N. Effect of soil salinity on growth, water status and nutrient accumulation in seedlings of Cassia montana (Fabaceae). Journal of Arid Environments, v. 70, n. 1, p. 174-182, 2007.

RADIĆ, S. et al. Salt tolerance of Centaurea ragusina L. is associated with efficient osmotic adjustment and increased antioxidative capacity. Environmental and Experimental Botany, v. 87, n. 1, p. 39-48, 2013.

RAISON, R. J. Opportunities and impediments to the expansion of forest bioenergy in Australia. Biomass and Bioenergy, v. 30, n. 12, p. 1021-1024, 2006.

SILVA, M. A. et al. Photosynthetic capacity and water use efficiency in sugarcane genotypes subject to water deficit during early growth phase. Brazilian Archives of Biology and Technology, v. 56, n. 5, p. 735-748, 2013.

STILLER, V. Soil salinity and drought alter wood density and vulnerability to xylem cavitation of baldcypress (Taxodium distichum (L.) Rich.) seedlings. Environmental and Experimental Botany, v. 67, n. 1, p. 164-171, 2009.

YEMM, E. W.; COCKING, E. C.; RICKETTS, R. E. The determination of amino-acids with ninhydrin. Analyst, v. 80, n. 948 , p. $209-214,1955$. 